\title{
SENI PERTUNJUKAN TARI ZAPIN API DI RUPAT UTARA BENGKALIS PROVINSI RIAU
}

\section{ZAPIN FIRE DANCE SHOW ARTS IN NORTH BENGKALIS RUPAT RIAU PROVINCE}

\author{
Nike Suryani dan Laila Fitriah \\ Seni, Drama, Tari, dan Musik, Fakultas Keguruan dan IImu Pendidikan UIR
}

Naskah diterima: 9 Juni 2018; direvisi: 8 Mei 2019; disetujui: 20 Juni 2019

\begin{abstract}
Abstrak
Tari zapin adalah salah satu jenis tarian yang ada di daearah Riau, hampir diseluruh kabupaten mempunyai tari zapin. Salah satunya tari zapin api, merupakan tradisi asli dari daerah Rupat Utara Tari zapin ini merupakan salah satu budaya lokal yang memiliki keunikan dan perbedaan dengan zapin lainnya. Tari Zapin Api adalah salah satu seni pertunjukan yang sangat terkenal di Kabupaten Bengkalis khususnya di daerah Rupat Utara. Tari Zapin Api merupakan sebuah pertunjukan yang menggabungkan tari dan musik dalam penampilannya. Tari zapin ini sangat erat hubungannya dengan alat musik gambus,.._Berdasarkan fenomena tersebut, penulis merasa perlu untuk melakukan penelitian yang lebih mendalam mengenai Unsur-unsur Tari Dan Unsur-unsur Musik pada tari Zapin Api. Dengan tujuan untuk mengetahui unsur tari Zapin Api dan unsur-unsur Musik. Teori dalam penulisan ini adalah teori seni pertunjukan memiliki fungsi yang sangat komplek dalam kehidupan manusia. Curh, nt Sachs mengutarakan, bahwa ada dua fungsi utama tari, yaitu (1) untuk tujuan-tujuan magis: dan (2) sebagai tontonan. Hal ini juga berhubungan dengan teori dari (Alan P. Merriam, 1987: 219-226) 10 fungsi musik yaitu: (1) pengungkapan emosional (2) pemuas rasa keindahan (3) hiburan (4) sarana komunikasi (5) persembahan simbolis (6) respon fisik (7) penguat norma-norma social (8) pengukuhan institusional dan upacara agama (9) sarana kelangsungan dan stabilitas kebudayaan, (10) perekat masyarakat. Subjek Penelitian 6 orang. Dalam buku Metodologi Penelitian Seni Pertunjukan dan Seni Rupa ( R.M. Soedarsono, 2001: 170) membagi seni pertunjukan ke dalam dua kelompok utama, yaitu fungsi primer dan sekunder dari seni pertunjukan. Subjek Penelitian 6 orang. Metode penelitian ini adalah jenis penelitian yang digunakan bersifat kualitatif dengan pendekatan etnokoreologi dan etnomusikologi.
\end{abstract}

Kata Kunci: Seni Pertunjukan,Tari Zapin , Tari Zapin Api

\begin{abstract}
Abstrack
Zapin dance is one type of dance in the region of Riau, almost all districts have zapin dance. One of them is the fire zapin dance, an original tradition from the North Rupat area. This zapin dance is one of the local cultures that has a unique and different from other zapin. The Zapin Api Dance is one of the most famous performing arts in Bengkalis, especially in the North Rupat area. The Zapin Api dance is a show that combines dance and music in its appearance. This zapin dance is very closely related to stringed instruments. Based on this phenomenon, the author feels the need to conduct more in-depth research on the Elements of Dance and Music Elements in the Zapin Api dance. With the aim of knowing the elements of the Fire Zapin dance and the elements of Music. The theory in this writing is that the performing arts theory has a very complex function in human life. Curh, nt Sachs said, that there are two main functions of dance, namely (1) for magical purposes: and (2) as a spectacle. This also relates to
\end{abstract}


the theory of (Alan P. Merriam, 1987: 219-226) 10 functions of music namely: (1) emotional disclosure (2) satisfying sense of beauty (3) entertainment (4) means of communication (5) symbolic offerings (6) physical response (7) reinforcement of social norms (8) institutional inauguration and religious ceremonies (9) means of cultural survival and stability, (10) community glue. Research Subjects 6 people. In the Performing Arts and Fine Arts Research Methodology book (R.M. Soedarsono, 2001: 170) divides the performing arts into two main groups, namely the primary and secondary functions of the performing arts. Research Subjects 6 people. This research method is a type of research that is used qualitatively with ethnocoreology and ethnomusicology approaches.

Keyword: Performing Arts, Zapin Dance, Zapin Api Dance

\section{PENDAHULUAN}

Indonesia adalah bangsa majemuk yang terkenal dengan keanekaragaman dan keunikannya. Indonesia terdiri dari berbagai suku bangsa yang mendiami belasan ribu pulau. Masing-masing suku bangsa memiliki keanekaragaman seni budaya tersendiri yang memiliki nilai-nilai sosial yang tinggi. Bangsa Indonesia merupakan gudang seni pertunjukan, khususnya seni tari dan musik tradisi.

Perjalanan dan bentuk seni tari di Indonesia sangat terkait dengan perkembangan kehidupan masyarakatnya, baik ditinjau dari struktur etnik maupun dalam lingkup Negara kesatuan. Jika ditinjau sekilas perkembangan Indonesia sebagai Negara kesatuan, maka perkembangan tersebut tidak terlepas dari latar belakang keadaan masyarakat Indonesia. Pada saat itu, Amerika
Serikat dan Eropa secara politis dan ekonomis menguasai seluruh Asia Tenggara, kecuali Thailand. Menurut Soedarsono (1977), salah seorang budayawan dan penelit seni pertunjukan Indonesia, menjelaskan bahwa secara garis besar perkembangan seni pertunjukan Indonesia tradisional sangat dipengaruhi oleh adanya kontak dengan budaya besar dari luar (asing).

Berdasarkan pendapat Soedarsono tersebut, maka perkembangan seni pertunjukan tradisional Indonesia secara garis besar terbagi atas periode masa pra pengaruh asing dan masa pengaruh asing. Apabila ditinjau dari perkembangan masyarakat Indonesia hingga saat ini, maka masyarakat sekarang merupakan masyarakat Indonesia dalam lingkup negara kesatuan. Tentu saja masingmasing periode telah menampilkan budaya yang berbeda bagi seni 
pertunjukan, karena kehidupan kesenian sangat tergantung pada masyarakat pendukungnya.

Dewasa ini perkembangan tari dan musik sangat pesat baik yang tradisional maupun yang moderen. Banyaknya jenis tari dan musik yang ada di Indonesia ini merupakan wujud dari beraneka ragamnya suku dan bahasa yang ada, sehingga beraneka macam pula tari dan musik yang ada di Indonesia. Setiap suku bangsa di Indonesia memiliki berbagai tarian dan musik khasnya sendiri-sendiri.

Provinsi Riau adalah salah satu Provinsi yang kaya akan budaya melayu di Indonesia. Riau sejak dahulu sudah menjadi daerah lalu lintas perdagangan Negara-negara tetangga, sehingga Riau melahirkan sosok dan warna budaya yang beragam. Riau mempunyai banyak kesenian tradisi, baik dari segi tari dan musiknya. Kesenian Riau tumbuh, hidup dan berkembang di pedalaman, di desa-desa terpencil, juga di kota-kota.

Tari zapin adalah salah satu jenis tarian yang ada di daearah Riau, hampir diseluruh kabupaten mempunyai tari zapin. Salah satunya tari zapin api, merupakan tradisi asli dari daerah Rupat Utara. Tradisi dapat diartikan dalam banyak hal. Dalam kepolosannya, pengertian paling dasar mengandung arti sederhana traditum yaitu segala sesuatu yang diteruskan atau dicapai dari masa lalu ke masa kini (Edward Shils, 2005: 14). Di Rupat Utara, zapin api mulai dimainkan sekitar tahun 1950an.

Pada awalnya, dibawa oleh Husein, ayah dari Abdullah, pemimpin dalam tarian zapin api saat ini. selain Abdullah, cuma ada M Nor yang mampu berperan sebagai khalifah atau pawang dalam pertunjukan zapin api. Abdullah dan $M$ Nor dulunya samasama berguru dengan Husein, sebelum dimulainya tarian zapin api ini, kemenyan yang berbau menyengat itu dibakar disebuah wadah seiring musik gambus dimainkan kemudian penari membalur diri mereka dengan asap hasil pembakaran kemenyan. Hal itu agar saat menari diatas bara api yang terbuat dari serabut kelapa tidak terjadi, apaapa, setelah diri mereka dimasuki roh leluhur. Tari zapin ini merupakan salah satu budaya lokal yang memiliki keunikan dan perbedaan dengan zapin lainnya . zapin ini merupakan salah satu potensi wisata yang harus tetap dilestarikan, hal inilah alasan penulis menarik untuk meneliti tari zapin ini baik secara teks dan konteks. 
Di Indonesia terdapat dua jenis Zapin, yaitu Zapin arab dan zapin melayu. Zapin arab disebut juga zapin lama, tumbuh dan berkembang di dalam kelompok masyarakat keturunan arab yang berada di berbagai tempat di Indonesiai, zapin Arab mengalami perubahan secara lamban, dan masih dipertahankan oleh masyarakat turunan Arab. Sementara zapin melayu berkembang di masyarakat melayu di seluruh Indonesia yang mempunyai kebebasan ungkap dalam batas sopansantun dan adat istiadat setempat, zapin Melayu yang ditumbuhkan oleh para ahli lokal, dan disesuaikan dengan lingkungan masyarakatnya. Kedua jenis tari zapin, yaitu zapin arab dan zapin melayu, menjadi warisan budaya indonesia yang memperkaya budaya bangsa dan menjadi sebagian dari kekuatan kesatuan bangsa yang tidak dapat saling dipisahkan satu dengan yang lainnya.

Zapin adalah istilah yang diambil dari kata dasar zaffa dalam bahasa arab bermakna "memimpin. Kata al-zafn yang di terjemahkan menjadi gerak kaki, menjadi asal kata dari kata zapin (mohd Anis Md Nor, 2000:64). Zapin salah satu media dakwah untuk menyebarluaskan nilai- nilai keislaman dan tunjuk ajar melayu. Tari zapin yang ada di Indonesia jelas memperlihatkan gerakan yang di rangkai dari gerak-gerak kaki. Gerak tangan terjadi secara wajar karena pengaruh gerak badan yang di akibatkan oleh gerak-gerak kaki. Pada umumnya pergerakan tari zapin melayu dititkberatkan kepada cara melangkah serta bunga-bunga langkah dengan hayunan tangan dan badan. Dahulunya tari zapin ini hanya ditarikan oleh lakilaki. Selain itu tarian ini berfungsi untuk upacara hari-hari besar islam, pernikahan.

Zapin digolongkan ke dalam kesenian yang diperkenalkan bersamaan dengan perkenalan agama islam. Berkembangnya zapin di Indonesia berkaitan dengan para pedagang dan penyebar agama islam dari Arab dan Gujarat. Sekarang kita dapat menemukan Zapin hampir diseluruh pesisir Nusantara, seperti : pesisir timur Sumatra Utara, Riau dan Kepulauannya, Jambi, Sumatra Selatan, Bangka Belitung, Bengkulu, Lampung, Jakarta, pesisir utara - timur dan selatan Jawa, Nagara, Mataram, Sumbawa, Maumere, Seluruh Pesisir Kalimantan, Sulawesi Selatan, Sulawesi Tengah, Gorontalo, Ternate, dan Ambon. Sedangkan 
dinegara tetangga terdapat di Brunei Darussalam, Malaysia, dan Singapura

Tari zapin ini sangat erat hubungannya dengan gambus, selain gambus alat iringan tari zapin yaitu warwas, vocal. Lagu-lagu yang digunakan banyak diambil dari lagulagu timur tengah dan mempunyai pantun atau syair berbahasa arab. Pola tarinya sangat sederhana dan dilakukan secara berulang-ulang. Gerak tarinya mendapat inspirasi dari kegiatan manusia dan alam lingkungan. Misalnya : titi batang, anak ayam patah, siku keluang, sut patin, pusing tengah, alif, dan lainnya. Pakaian Didalam Tarian Zapin mempunyai pengaruh Arab-Parsi, tetapi dari segi pakaian penari, penari memakai pakaian Melayu selengkapnya yaitu bagi laki-laki berkain samping, memakai baju teluk belanga, cekak musang, memakai kain sarung tenunan siak, dan bersongkok sedangkan wanita memakai kurung, kain sarong, kebaya panjang, hiasan kembang goyang untuk sanggul, gelang atau dukuh.

Zapin melayu yang berkembang di kepulauan Riau merupakan adaptasi dari zapin arab yang dibawa oleh pedagang-pedagang dari timur tengah yang menyinggahi pelabuhan-pelabuhan di alam melayu. Kesenian zapin diperkirakan masuk ke kepulauan Riau. Kesenian zapin pada awalnya dimaksudkan sebagai sarana yang berhubungan dengan syiar agama, dimeriahkan dengan pukulan gendang marwas dan petikan gambus sambil menyanyikan lagu-lagu pujian terhadap Allah SWT dan para nabi.

Pada awalnya tari dan musik hanya dipergunakan untuk sebuah upacara ritual adat, media hiburan, media ekspresi diri, media komunikasi, pengiring tari, dan sarana ekonomi. Tari pada dasarnya merupakan penampilan gerak tubuh, oleh karena itu tubuh sebagai media ungkap sangat penting perannya bagi tari. Gerakan tubuh dapat menjadi sebuah bagian dari komunikasi bahasa tubuh, dengan itu tubuh berfungsi menjadi bahasa tari untuk memperoleh makna gerak. Tari merupakan salah satu cabang seni yang mendapat perhatian besar di tengah masyarakat, tari menjadi media komunikasi yang universal yang dapat dinikmati oleh siapa saja dan kapan saja.

Musik merupakan salah satu media ungkapan kesenian, musik mencerminkan kebudayaan masyarakat pendukungnya. Dalam kamus besar Bahasa Indonesia (1990: 602) musik 
adalah ilmu atau seni menyusun nada atau suara yang diutarakan, kombinasi dan hubungan temporal untuk menghasilkan komposisi (suara) yang mempunyai keseimbangan dan kesatuan nada atau suara yang disusun sedemikian rupa sehingga mengandung irama, lagu dan keharmonisan (terutama yang dapat menghasilkan bunyibunyian).

Musik pada iringan tari berfungsi sebagai pengiring dari sebuah tarian, tidak hanya keluar sebagai suara saja, tetapi musik yang mengatur gerak, sebagai penegas dalam membentuk karakter penari, sehingga maksud dari satu tarian itu dapat dipahami oleh penikmatnya. Menurut (Soedarsono, 1976: 26) mengatakan elemen dasar tari adalah gerak dan ritme. Maka elemen dasar dari musik adalah nada, ritme dan melodi. Jadi dapat dikatakan dimana ada tari disitu pasti ada musik. Musik dalam tari bukan hanya sekedar pengiring, tetapi musik adalah partner tari yang tidak boleh ditinggalkan.

Musik dalam tari memiliki peran penting dalam memperkuat keutuhan penyajian tari. Kedudukannya tidak hanya mampu sebagai pengiring tarian saja, melainkan mampu pula berperan sebagai penguat suasana dan penekanan terhadap penyampaian dari makna gerak yang dipresentasikan. Keberadaan musik dalam tari merupakan hal yang sangat penting. Peranan atau kedudukan musik dalam tari bukan sebagai pengiring, melainkan sebagai musik tari.

Musik yang dimainkan untuk mengiringi pertunjukan zapin api merupakan musik yang berkelompok dalam artian ansambel kecil yang terdiri dari gambus yang berfungsi memainkan melodi pokok dan diiringi dengan dua gendang melayu atau biasa disebut juga dengan gendang ronggeng. Musik dimainkan dengan tempo lambat dimana melodi dari gambus memainkan rangkaian pola yang repetititf (pengulangan),sedangkan gendang memainkan pola yang biasa dikenal dengan pola zapin.

Dalam pertunjukan ini terdapat juga musik internal dari penari zapin. Penari memukul-mukul sebuah batok kelapa mengikuti ritme gendang dan ada beberapa penari yang bertepuktepuk tangan mengikuti pola ritme yang dimainkan oleh para pemusik. Secara keseluruhan musik yang mengiring pertunjukan zapin ini berbentuak linear atau bisa dikatakan memiliki satu bentuk bagian musik yang dimainkan 
dari awal pertunjukan sampai akhir tarian.

\section{METODE PENELITIAN}

Dalam penelitian ini penulis memilih tempat penelitian di daerah Rupat Utara, Bengkalis. Lokasi ini dipilih karena hanya daerah ini yang memiliki pertunjukan Zapin Api, sehingga membuat peneliti tertarik untuk meneliti pertunjukan ini. Waktu penelitian akan dilaksanakan pada bulan Juni sampai bulan Oktober. Berkaitan dengan permasalahan dalam penelitian ini, maka jenis penelitian yang digunakan bersifat kualitatif dengan pendekatan etnokoreologi dan etnomusikologi.

Sebagai langkah awal dalam penelitian ini dimulai dengan mengumpulkan materi yang berhubungan dengan topik yang akan diteliti. Dengan melakukan studi pustaka tentang Seni Pertunjukan Tari Zapin khususnya Tari Zapin Api. Sumber pustaka sebagai data tertulis berupa buku, laporan penelitian, serta dokumen tentang Tari Zapin Api. Hal ini dilakukan untuk memperoleh suatu keabsahan bagi suatu penelitian. Selanjutnya peneliti menentukan lokasi penelitian yaitu daerah Rupat Utara Bengkalis Provinsi Riau. Langkah awal yang dilakukan yaitu terjun ke lapangan untuk berjumpa langsung dengan subjek penelitian yang berjumlah sembilan orang yang terdiri dari satu orang yang mengetahui tentang seluk beluk Tari Zapin Api, dan lima orang penari serta tiga orang pemusik.

Alat bantu yang digunakan dalam penelitian ini untuk mengumpulkan data yaitu berupa kamera foto (kamera digital, dan camera handphone) untuk mendapatkan fotofoto pertunjukan Tari Zapin Api, dan suasana pertunjukannya. Sebelum diadakan penelitian lapangan terlebih dahulu dilakukan studi pustaka untuk mengetahui Seni Pertunjukan Tari Zapin Api di Rupat Utara Bengkalis Provinsi Riau dalam bentuk tulisan, baik tulisan yang berhubungan secara langsung dengan permasalahan maupun yang tidak secara langsung.

Peneliti menggunakan teknik wawancara terbuka. Peneliti dapat bertanya kepada informan kapan saja dan dimana saja. Untuk menentukan informan yang informative dan bisa memberikan penjelasan seorang informan itu harus paham terhadap data yang dibutuhkan. Pengumpulan data di lapangan yang berkaitan dengan pencatatan data dan perekaman, 
digunakan alat bantu seperti: video, camera, dan buku catatan. Dokumentasi sangat diperlukan karena bertujuan untuk memberikan gambaran yang jelas terhadap data yang sudah diperoleh. Untuk itu peneliti melampirkan beberapa foto-foto sebagai bukti dari hasil penelitian.

Analisis data dilakukan dengan tahap berpedoman pada prinsip keterkaitan antara kepustakaan dengan data yang diperoleh, kemudian menentukan kerangka ilmiah dari objek penelitian. Data mentah yang telah dikumpulkan oleh peneliti tidak aka nada gunanya jika tidak dianalisis.

Data yang didapat dari hasil wawancara yang telah peneliti dapatkan semuanya ditulis sesuai dengan jawaban yang diberikan informan berdasarkan pertanyaan yang diberikan. Setelah semuanya terkumpul peneliti menjelaskan dalam bentuk tulisan yang bisa menjawab pertanyaan penelitian yang diolah dan dianalisis berdasarkan pendekatan yang telah ditetapkan.

SEJARAH DAN PERKEMBANGAN TARI ZAPIN API DI RUPAT UTARA

$$
\text { Kemajemukan masyarakat }
$$

Indonesia mengakibatkan kemajemukan budaya Indonesia. Salah satu kebudayaan tersebut berbentuk kesenian daerah. Ada banyak sekali kesenian daerah yang ada di Indonesia. Kesenian adalah bagian dari budaya dan merupakan sarana yang digunakan untuk mengekspresikan rasa keindahan dari dalam jiwa manusia. Kesenian adalah salah satu di antara tujuh unsur kebudayaan yang bersifat universal.

Tari Zapin Api merupakan salah satu kesenian tari tradisional dari desa Teluk Rhu Kecamatan Rupat Utara, Kabupaten Bengkalis Provinsi Riau. Tarian Zapin Api hadir ditengah masyarakat sebagai tradisi yang terus dilestarikan secara turun temurun. Berdasarkan hasil wawancara penulis dengan M. hapis- Khalifah Zapin Api (27 November 2017) sejarah Tari Zapin Api berawal dari sebuah tarian bernama Tari Api. Tari ini berawal ketika pulau Rupat diduduki oleh Bangsa Melayu pelarian dari Melaka. Pada saat itu banyak peristiwa dan bencana alam yang terjadi di Pulau Rupat, melalui 4 (empat) unsur alam yaitu api, air, tanah dan angin. Pada saat itu ada 4 (empat) orang pawang besar yaitu pawang api, pawang angin, pawang tanah dan pawang air. Mereka berempat setuju untuk menjaga Pulau rupat dan melakukan perundingan dengan jin 
yang menguasai 4 (empat) unsur alam tersebut.

Pada saat pertama kali perundingan dilakukan, salah satu unsur yang dikawal oleh Jin api tidak mau melakukan perundingan dengan pawang api. Jin api akan datang apabila dia disambut dengan sebuah tarian. Dengan inisiatif cepat, pawang api memanggil masyarakat yang hadir pada waktu itu untuk berdiri dan membuka baju melakukan gerakan bebas dengan menepukkan tangan untuk menyambut kehadiran Jin api. Setelah itu terjadilah perundingan antara pawang api dengan jin api untuk menghindari bencanabencana di Pulau Rupat. Saat pertama kali Tari Api ini dilakukan dengan tari biasa dan tidak dilakukan dengan api. Seiring waktu berjalan dikarenakan kekuatan jin api, dia meminta pawang api agar penyambutan jin api dilakukan dengan menggunakan api. Jin api melewati pawang sebagai perantaranya memberi beberepa syarat atau mantra yang harus diamalkan oleh masyarakat yang ingin menari api.

Menurut

Koentjaraningrat (2009:110-111) penyebaran unsur-unsur kebudayaan dapat juga terjadi tanpa ada perpindahan kelompok-kelompok manusia atau bangsa-bangsa dari suatu tempat ke tempat lain, tetapi oleh karena adanya individu-individu tertentu yang membawa unsur-unsur kebudayaan itu hingga jauh sekali. Mereka itu terutama pedagang dan pelaut. Pada zaman penyebaran agamaagama besar para pendeta agama budha, nasrani dan kaum muslimin mendifusikan berbagai unsur dari kebudayaan-kebudayaan dari mana mereka berasal. Hal inilah yang mempengaruhi masuknya Tari Zapin Api di Rupat Utara.

Setelah pertengahan abad 15 pengaruh Islam masuk ke Pulau Rupat melalui Bangsa Aceh berketurunan Arab, maka Tari Api dirubah bentuknya menjadi sebuah tarian yang menggunakan musik yang berunsurkan Zapin dengan alasan dalam Zapin Api banyak menggunakan shalawat nabi, sejarah Nabi dan kebesaran ilahi. Kemudian para penari-penarinya setelah masuknya Islam tidak diperbolehkan lagi menggunakan mantra-mantra yang berunsurkan dari Jin Api. Para penari diberikan sebuah amalan yang tidak bertolak belakang dengan syariat Islam, biasanya para penari Zapin Api dianjurkan untuk membuat amalan yang berunsur Islam seperti puasa, dzikir, sholat, dan apabila penari Zapin Api 
membuat langgaran atau pantangan yang bertentangan dengan syariat Islam dia tidak akan bisa menari di atas Api.

Pada awal perkembangannya Tari Zapin Api mulai dikenal oleh masyarakat sekitar tahun 1950. Berdasarkan hasil wawancara dengan M. Hapis pada tahun 1980-1990an Tari Zapin Api ini sempat tidak pernah dimainkan, karena tidak adanya generasi penerus. Tetapi setelah mendapatkan mimpi M.Hapis merasa ada panggilan untuk dirinya, agar meneruskan sanggar atau kelompok Tari Zapin Api yang telah dibina oleh orangtuanya.

Menurut Musrial Mustafa (wawancara, 27 November 2017) Tari Zapin Api mulai hadir kembali pada tahun 2006, tetapi baru mulai eksis dan aktif kembali pada tahun 2008. Tari Zapin Api dimainkan atau diperkenalkan kembali oleh Abdul Jafar, ayah dari M.Hafiz yang menjadi bidu atau khalifah Tari Zapin Api saat ini. Tari Zapin Api mulai dikenal oleh banyak orang, baik masyarakat setempat maupun tamu yang datang dari luar pulau Rupat.

SENI PERTUNJUKAN TARI

ZAPIN API
Menurut Edi Sedyawati (2006), jejak-jejak seni pertunjukan Indonesia mulai ditemukan pada zaman prasejarah akhir, terutama pada zaman perunggubesi. Buktinya adalah ditemukannya beberapa logam hasil zaman itu berisi sejumlah penggambaran mengenai orang-orang menari dengan mengenakan hiasan kepala dengan bulubulu panjang serta topeng. Hal ini juga diperkuat oleh lukisan-lukisan zaman ini yang banyak menggambarkan orang menari. Seni pertunjukan Indonesia mengalami perkembangan pada masa Hindu-Budha. Sumber-sumber tertulis menunjukkan bahwa relief-relief candi menggambarkan orang menari.

Indonesia memiliki banyak jenis tarian. Tari-tarian tersebut sudah dikenal sejak dulu, baik yang berkembang dalam masyarakat ataupun yang dikenal di lingkungan istana. Menurut Bagus Susetyo (2007:1-23) seni pertunjukan merupakan sebuah ungkapan budaya, wahana untuk menyampaikan nilai-nilai budaya dan perwujudan norma-norma estetikartistik yang berkembang sesuai dengan zaman, dan wilayah dimana bentuk seni pertunjukan itu tumbuh dan berkembang. Dalam mengkaji seni pertunjukan dapat pula ditinjau dari 
perspektif sosial, ekonomi, dan politik, suatu Negara atau daerah dimana bentuk seni pertunjukan tersebut tumbuh dan berkembang. Kebijakankebijakan suatu daerah sangat mempengaruhi maju tidaknya seni pertunjukan di daerah tersebut.

Tari merupakan ungkapan manusia yang dinyatakan dengan gerakan-gerakan tubuh manusia. Hakikatnya bahwa tari merupakan gerak. Dalam kamus Bahasa Indonesia dinyatakan bahwa: "Tari adalah gerakan badan (tangan dan sebagainya) yang berirama dan biasanya diiringi dengan bunyi-bunyian (musik dan instrument musik). Menurut Poerwadarminta (1976) gerak-gerak dari bagian tubuh manusia yang disusun secara indah dan diselaraskan dengan musik yang mempunyai maksut dan tujuan tertentu disebut dengan seni tari.

Seni tari adalah sebuah ekspresi jiwa manusia yang diwujudkan melalui gerak keseluruhan tubuh yang indah. Gerak ini ditata dengan musik pengiring sesuai dengan watak dan tema tari. Tari Zapin Api adalah salah satu seni pertunjukan yang sangat terkenal di Kabupaten Bengkalis khususnya di daerah Rupat Utara. Tari Zapin Api merupakan sebuah pertunjukan yang menggabungkan tari dan musik dalam penampilannya. Pertunjukan Tari Zapin Api mengandung unsur-unsur tari atau elemen-elemen tari didalamnya seperti gerak, musik, desain lantai, dinamika, tata rias, tata busana, dan penonton.

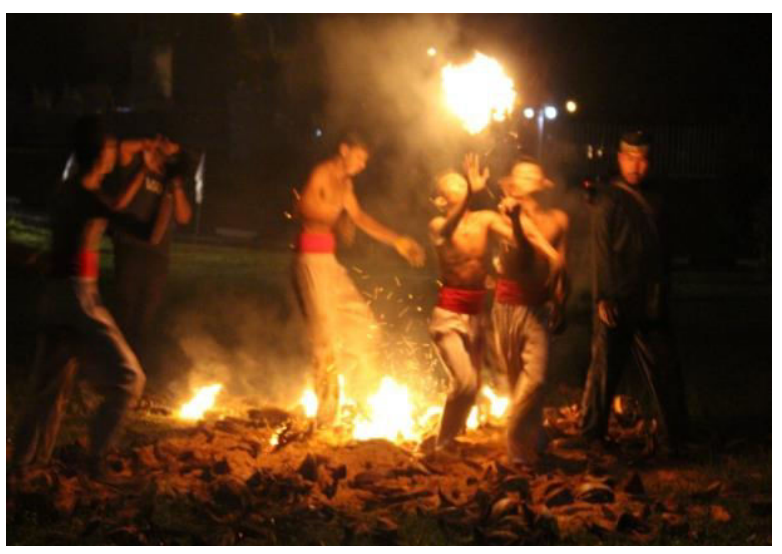

Gambar 1: Pertunjukan Tari Zapin Api (27 November 2017)

Menurut Soedarsono (2003:199) gerak tidak hanya terdapat pada denyutan-denyutan diseluruh tubuh manusia yang hidup, tetapi didalam gerak juga terdapat ekspresi dari segala pengetahuan emosioanal manusia. Sebagaimana yang dijelaskan, gerak adalah pengalaman fisik yang paling elementer dari kehidupan manusia. Gerakan-gerakan pada tari zapin api lebih memusatkan pada gerakan tangan dan kaki, gerakannya hanya bersifat sederhana.

Gerak tari merupakan unsur utama dari tari. Gerak tari selalu 
melibatkan unsur anggota badan manusia. Gerak tari adalah sebuah proses perpindahan satu sikap tubuh satu ke sikap tubuh lainnya. adanya proses tersebut, maka gerak dapat dipahami sebagai kenyataan visual (hidayat, 2005:72). Ragam gerak dari tari zapin masih mengambil dari ragam gerak tari api yaitu tepuk tangan. Gerakan yang dilakukan oleh penari lebih terlihat secara spontanitas dan sederhana tidak menggunakan teknik dalam bergerak. tetapi masih mengikuti irama dari gendang bebano dan gambus. Pada saat melakukan gerakan si penari sudah merasa tidak di alam nyata mereka bergerak keluar masuk kedalam api, si penari beranggapan api merupakan perumpamaan sebagai seorang perempuan cantik.

Menurut Y. Sumandiyo Hadi (2003: 51) tari sebagai dalam sajiannya tidak pernah terlepas dari musik pengiring, karena dalam hal ini antara tari dan musik erat berhubungan. Musik sebagai pengiring tari dapat dipahami, pertama, sebagai iringan ritmis gerak tarinya; kedua, sebagai ilustrasi pendukung suasana tarinya; dan ketiga, dapat terjadi kombinasi keduanya secara harmonis.
Dalam bukunya Marcel Danesi (2004: 244-245) juga mengatakan musik sering dipergunakan untuk mengiringi aktivitas lain. Secara universal musik dihubungkan dengan tarian. Musik merupakan komponen utama dalam banyak jenis kebaktian religious, ritual sekuler, dan teater. Dalam beberapa masyarakat musik juga merupakan aktivitas yang dilakukan semata-mata demi musik itu sendiri.

Masuknya agama Islam ke Indonesia memberi pengaruh unik terhadap seni pertunjukan Indonesia, khususnya seni musik. Pengaruh Islam ditemukan pada musik yang dimainkan dalam pertunjukan Tari Zapin Api. Musik pembuka dan penutup Zapin Api adalah berirama zapin. Lagu yang agak cepat sebagai pembuka biasanya lagu yang dibawakan lagu Siti Fatimah, lagu Syekh Abdul Kadir Al-Jaelani dan lagu lainnya. Setelah para penari telah mulai masuk ke api, maka lagu yang dipakai adalah lagu seperti zapin tradisi lainnya. Untuk musik penutup dipakai musik zapin yang lambat agar penari juga melemah sehingga Khalifah Zapin Api dapat menyadarkan para penari.

Musik dalam Tari Zapin Api sangat erat hubungannya dengan tari karena sama-sama berasal dari 
dorongan atau naluri ritmis manusia (murgiyanto, 1983: 43). Iringan atau musik dapat dibentuk menjadi dua yaitu musik internal dan musik eksternal. Musik internal ialah musik yang ditimbulkan dari dalam diri penari, sedangkan musik eksternal adalah musik yang ditimbulkan dari luar diri penari.

Musik yang digunakan dalam tari zapin api adalah musik eksternal dengan menggunakan alat musik pengiring tari. Alat musik yang digunakan dalam Tari Zapin Api adalah alat musik gambus, gendang bebano dan lagu-lagu zapin, musik sangat berpengaruh penting terhadap tarian, sebagai pengatur dalam sebuah pertunjukan. sebelum memainkan alat musik ada bebarapa syarat-syarat tertentu yaitu memandikan alat musik terlebih dahulu dengan aia limau, kemudian untuk alat musik gambus diasapi dengan kemenyan.

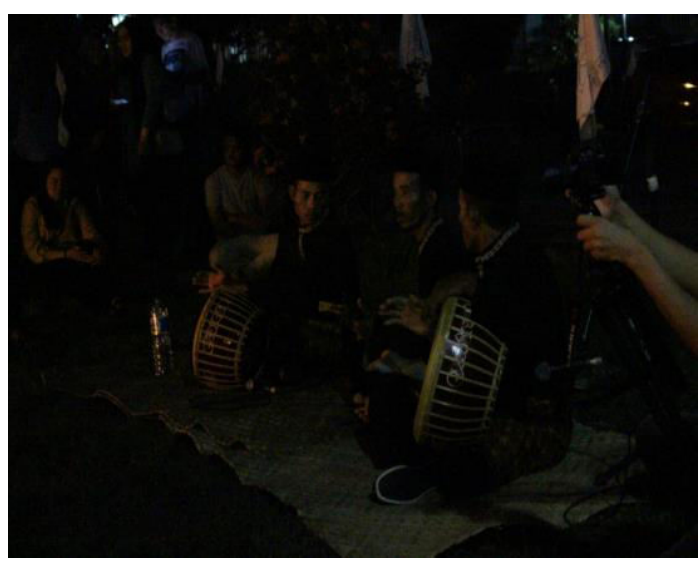

Gambar 2: Alat musik Tari zapi api (27 November 2017)

Menurut R. Supanggah (1995:3) Etnomusikologi adalah sebuah studi musik tradisional yang dipelajari secara lisan atau turun temurun dan tidak melalui tulisan. Biasanya musik tradisi diajarkan turun temurun dari nenek moyang terdahulunya, dan berkembang hingga saat ini. Musik pengiring dalam pertunjukan Tari Zapin Api didapatkan oleh bidu atau khalifah dari orangtuanya secara langsung.

Dalam melakukan sebuah pertunjukan ada beberapa hal dan ketentuan yang harus diikuti oleh para pemain, baik dari sipenari maupun pemain musik yang mengiring tarian tersebut. Hal-hal yang perlu dipersiapkan yaitu:

1. Persiapan lokasi Tari Zapin Api

2. Memandikan alat musik utama (gambus) yang dimainkan oleh bidu atau khalifah.

3. Khalifah tidur bersama alat musik utama (gambus) sehari sebelum pementasan dilakukan.

4. Memandikan alat musik pendukung.

5. Berwudu oleh semua pelaku atau pemain Tari Zapin Api sebelum melakukan pertunjukan. 
6. Satu minggu menjelang pertunjukan pemain Tari Zapin Api melakukan puasa senin kamis.

7. Musik Zapin dimainkan oleh bidu atau khalifah pertanda pertunjukan akan segera dimulai.

8. Penari dan pawang mulai masuk ke arena pertunjukan.

9. Pementasan Tari Zapin Api.

10. Musik semakin dipercepat

11. Petugas penjaga api atau pawang menghidupkan api pada sabut kelapa kering yang sudah disiapkan.

12. Petugas penjaga api atau pawang juga menjaga para penari untuk tidak masuk ke api, jika api belum membesar dan mengumpulkan bara api yang berserakan supaya jangan sampai keluar dari arena permainan dan mengenai penonton.

\section{FUNGSI TARI ZAPIN API DI RUPAT UTARA}

Pada dasarnya, sebuah seni pertunjukan memiliki fungsi yang terkait dengan pemenuhan kebutuhan manusia. Beberapa fungsi dari pertunjukan tersebut antara lain: fungsi religius, fungsi sosial, fungsi hiburan, fungsi estetik.

Fungsi Tari Zapin Api dari masa pertama sekali dibentuk bukanlah sebagai pertunjukan hiburan, tetapi lebih kepada pengembangan atau pengenalan Islam. Seorang pengembara dari Bangsa Aceh yang bernama Said Jafar, dialah orang yang pertama sekali menggubah Tari Api menjadi Zapin Api. Setelah itu dirubah lirik lagu yang memuja-muji Nabi, maka Zapin Api digunakan untuk mengembangkan Agama Islam di Pulau Rupat.

Setelah masuk abad 19 Tari Zapin Api sudah mulai diminati oleh hampir seluruh masyarakat Pulau Rupat, sehingga Zapin Api ini mulai dijadikan sarana hiburan pertunjukan disetiap acara sunatan, pesta pernikahan, acara sapar dan hari-hari besar yang ada di Pulau Rupat. Zapin Api ini juga dijadikan sebagai wisata budaya di Kabupaten Bengkalis. Kesenian Zapin Api sebagai salah satu bentuk kreatifitas seni budaya yang unik.

Menurut Soedarsono (2001:170) seni pertunjukan dapat dibagi kedalam 2 (dua) kelompok utama, yaitu fungsi primer dan sekunder dari seni pertunjukan. Teori ini juga dapat menunjang permasalahan yang terjadi dalam penelitian yaitu adanya fungsi primer dari pertunjukan Tari Zapin Api. Ada 3 (tiga) fungsi yaitu: (1) sebagai sarana ritual, penikmatnya adalah 
kekuatan-kekuatan yang tak kasat mata,

(2) sebagai sarana hiburan pribadi, penikmatnya adalah pribadi-pribadi yang melibatkan diri dalam pertunjukan, (3) sebagai presentasi estetis yang pertunjukannya harus dipresentasikan atau disajikan kepada penonton.

Fungsi primer yang ada dalam pertunjukan Tari Zapin Api yaitu: (1) sebagai sarana ritual, dahulunya Tari Zapin Api dijadikan sarana untuk memanggil jin api yang berguna untuk melindungi daerah rupat dari mara bahaya, (2) sebagai sarana hiburan pribadi, penikmatnya adalah pribadipribadi yang melibatkan diri dalam pertunjukan. Dalam pertunjukan Tari Zapin Api melibatkan banyak penari dan tergolong dari berbagai jenis usia, menurut para penari dan pemusik alasan mereka menjadi pemain Tari Zapin Api untuk mengembangkan hobi mereka dan menajadi sarana hiburan, untuk berkumpul dengan teman-teman setelah letih bekerja dan mereka bermain Tari Zapin Api, (3) sebagai presentasi estetis yang pertunjukannya harus disajikan kepada penonton. Dalam hal ini tari Zapin Api juga memiliki banyak penonton dan penikmat disetiap pertunjukannya.
Dalam hal ini fungsi musik dalam pertunjukan Tari Zapin Api juga memili fungsi yaitu: (1) pengungkapan emosional, bagi pemain musik yang mengiringi penari dengan bermain musik dapat mengungkapkan emosional atau perasaan mereka yang dituangkan melalui musik, (2) hiburan, dengan adanya musik dalam Tari Zapin Api dapat menghibur banyak orang yaitu penonton yang menyaksikan pertunjukan tersebut, (3) sarana komunikasi, dalam hal ini musik sangat berperan penting untuk sarana komunikasi si penari dan si pemusik dalam pertunjukannya, (4) perekat masyarakat, dengan hadirnya kembali Tari Zapin Api membuat masyarakat di Rupat Utara berbondong-bondong menyaksikan pertunjukan ini dan mereka akan saling berinteraksi satu sama lainny

\section{KESIMPULAN}

Tari Zapin Api merupakan salah satu kesenian tari tradisional dari desa Teluk Rhu Kecamatan Rupat Utara, Kabupaten Bengkalis Provinsi Riau. Tarian Zapin Api hadir ditengah masyarakat sebagai tradisi yang terus dilestarikan secara turun temurun sampai saat ini. Fungsi Tari Zapin Api dari masa pertama sekali dibentuk 
bukanlah sebagai pertunjukan hiburan, tetapi lebih kepada pengembangan atau pengenalan Islam. Seorang pengembara dari Bangsa Aceh yang bernama Said Jafar, dialah orang yang pertama sekali menggubah Tari Api menjadi Zapin Api. Setelah itu dirubah lirik lagu yang memuja-muji Nabi, maka Zapin Api digunakan untuk mengembangkan Agama Islam di Pulau Rupat.

Berhubung

perkembangan zaman dengan kebutuhannya Tari Zapin Api berubah fungsi menjadi pertunjukan hiburan bagi masyarakat. Seni pertunjukan dapat dibagi kedalam 2 (dua) kelompok utama, yaitu fungsi primer dan sekunder dari seni pertunjukan. Fungsi primer yang ada dalam pertunjukan Tari Zapin Api yaitu: (1) sebagai sarana ritual, dahulunya Tari Zapin Api dijadikan sarana untuk memanggil jin api yang berguna untuk melindungi daerah rupat dari mara bahaya, (2) sebagai sarana hiburan pribadi, penikmatnya adalah pribadi-pribadi yang melibatkan diri dalam pertunjukan. Dalam pertunjukan Tari Zapin Api melibatkan banyak penari dan tergolong dari berbagai jenis usia, menurut para penari dan pemusik alasan mereka menjadi pemain Tari Zapin Api untuk mengembangkan hobi mereka dan menajadi sarana hiburan, untuk berkumpul dengan teman-teman setelah letih bekerja dan mereka bermain Tari Zapin Api, (3) sebagai presentasi estetis yang pertunjukannya harus disajikan kepada penonton. Dalam hal ini tari Zapin Api juga memiliki banyak penonton dan penikmat disetiap pertunjukannya.

Dalam hal ini fungsi musik dalam pertunjukan Tari Zapin Api juga memiliki fungsi yaitu: pengungkapan emosional, bagi pemain musik yang mengiringi penari dengan bermain musik dapat mengungkapkan emosional atau perasaan mereka yang dituangkan melalui musik, (2) hiburan, dengan adanya musik dalam Tari Zapin Api dapat menghibur banyak orang yaitu penonton yang menyaksikan pertunjukan tersebut, (3) sarana komunikasi, dalam hal ini musik sangat berperan penting untuk sarana komunikasi si penari dan si pemusik dalam pertunjukannya, (4) perekat masyarakat, dengan hadirnya kembali Tari Zapin Api membuat masyarakat di Rupat Utara berbondong-bondong menyaksikan pertunjukan ini dan mereka akan saling berinteraksi satu sama lainnya. 


\section{DAFTAR PUSTAKA}

Danesi, Marcel. Pesan, Tanda, dan Makna: Buku Teks Dasar Mengenai Semiotika dan Teori. Yogyakarta: Jalasutra, 2010.

Edraswara, Suwardi. Metodologi Penelitian Kebudayaan. Yogyakarta: Gadjah Mada Universitas Press, 2006.

Hadi, Y. Sumandiyo. Koreografi Kelompok. Yogyakarta : Cipta Media, 2012

Koentjaraningrat. Sejarah Antropologi I. Jakarta: Universitas Indonesia Press, 2009.

Merriam, Alan P. The Anthropology of Music. Evanston : Northwestern University Press, 1987.

Miles, B. Mathew dan Michael Huberman. Analisis Data Kualitatif Buku Sumber Tentang Metode-metode Baru. Jakarta: UIP, 1992.

Mohd. Anis \& Md Nor. Zapin Melayu Nusantara. 2000.

Murgianto, S. Koreografi Pengetahuan Dasar Komposisi Tari. Departemen Pendidikan dan Kebudayaan, 1983

Nasir, Moh. Metode Penelitian. Bogor: Ghalia Indonesia, 2005.

Poerwadarminta W.J.S. Kamus Umum Bahasa Indonesia. Jakarta: PN Balai pustaka, 1976.

R. Brandon James. Jejak-jejak Seni Pertunjukan Di Asia Tenggara. Bandung: P4ST UPI, 2003.

Soedarsono, R.M. Mengenal Tari-tarian Rakyat di Daerah Istimewa Yogyakarta. Yogyakarta: Akademi Seni Tari Indonesia, 1976. - Seni Pertunjukan Indonesia di Era
Globalisasi. Yogyakarta: Gadjah Mada University Press, 2002.

Metodologi

Penelitian Seni Pertunjukan dan Seni Rupa. Bandung: Masyarakat Seni Pertunjukan Indonesia, 2001.

Supanggah, R. Ethnomusikologi. Yogyakarta: Yayasan Bentang Budaya, 1995.

Susetyo, Bagus. Pengkajian Seni Pertunjukan. Semarang: Sendratasik FBS UNNES, 2007.

Sedyawati, Edi. Budaya Indonesia: Kajian Arkeologi, Seni, dan Sejarah. Jakarta: Raja Grafindo Persada, 2006. 